\title{
A possibilist analysis of the Geography National Curriculum in England $^{1}$
}

\author{
David Lambert and John Hopkin²
}

\begin{abstract}
This article presents an analysis of the national curriculum for geography as it has evolved in England since its inception in 1991 following the Education Reform Act of 1988. Whilst the main contents of our original analysis are provided by way of a table, enabling the reader ready access to the broad trends we identify in how geography has been expressed in the national curriculum over a period of some 25 years, the main purpose of the article is to focus on the current reforms in England. This takes the form of a brief, and yet precise, 'knowledge-led' national curriculum programme of study introduced to a radically marketised school system in which choice and local autonomy are emphasised and encouraged. Our discussion leads us to speculate on the possibility of teachers reclaiming professional responsibility for the curriculum rather than the state, based on a progressive discipline oriented vision of geography in education.
\end{abstract}

\section{Introduction}

As we write this the national curriculum in England has been reviewed again - the fourth time since its introduction for the first time in 1991. The current reforms, for first teaching in September 2014, are far reaching and have deep implications which we discuss in detail in this paper. Our analysis uses a framework derived from Young and Muller (2010) deployed to help envision the kind of curriculum that might be possible to implement in schools. This is our 'possibilist' interpretation of a curriculum for engagement (if not survival - see Lambert 2013), and we are aware that this could be different from that which government may have intended.

Our analysis also is placed in historical perspective. To the lay person the frequency of change to the national standards as set out in the national curriculum is quite possibly perplexing. However, as teachers and educationists know very well, reviewing the national curriculum is never a simple matter: it is not simply a matter of updating the content (see for example the discussion by Winter 2009; 2011;

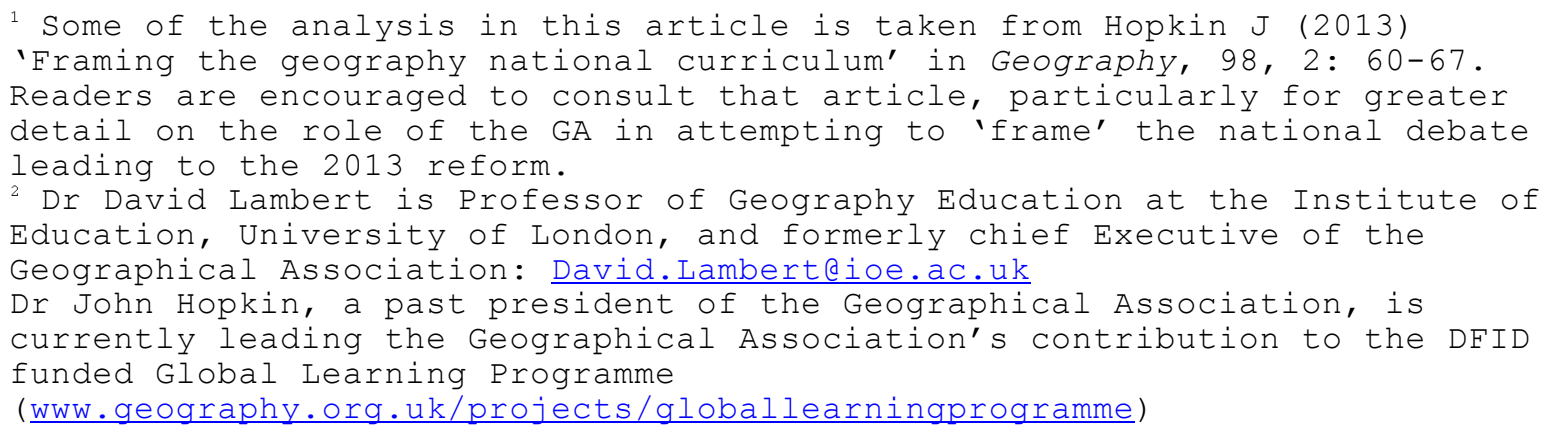


2012). There are deep seated and contentious matters to confront, which in England at least rarely get settled or resolved for any length of time. Indeed, on the contrary, they can become highly politicised. Our notions of childhood for example (Biddulph 2011; 2013), let alone our idea of knowledge and its purposes (Firth 2013), influence enormously what we think the curriculum is and what form it should take. Our values regarding what we believe schools to be for also help position us as individual members of society and as educationists (see for example Lawton 1989; or more recently Reiss and White 2013). In geography, Bill Marsden's analysis in the latter years of the last century has been useful in identifying the historical dynamic between three domains:

- the child, their perceived needs and our understanding of learning; these are according to Marsden broadly 'educational' matters

- the subject, defined in terms of selecting the best of what we know and inducting students into the processes and procedures of how we have come to know it

- social purposes, or what Marsden called 'good causes' which can serve political purposes and subvert some notions of education.

We use this schema as a way-in to our own historical analysis of the evolving national curriculum in England between 1991 and 2014. It is, as our main table (Table 1) attempts to show, possible to discern over this period the waxing and waning of these domains in relation to each other, within a broader context of a growing divide between the school subject and geography's emergent disciplinary history (see Stoddard 1981). In this context the 2014 reform of the national curriculum can be interpreted as a response to redress the balance whereby an overreaching personalisation of the curriculum, and a concomitant concern for skills and learning processes, had undermined what ministers (and others) refer to as 'subject rigour' (Standish 2012).

The thread running through the whole article is, unsurprisingly, our interest in the concept of curriculum. We need to make this explicit, for conceptually 'curriculum' has become confused - partly due to its close association in practitioners' minds with pedagogy and partly due to its concrete manifestation in school leaders' heads as the timetable. For us curriculum is not a managerial device or tool. It is one of only very few ideas genuinely to have emerged from educational studies. In other words, it is an idea that almost defines education: at least, curriculum lies close to the core purpose of schools and why societies choose to send children to school, by law. Conceptually, we distinguish curriculum as being concerned with the overriding question of what to teach the young. This is a difficult and profound question. It is conceptually distinct from the question of how to teach although we readily and eagerly concede that in practice the two may be very closely intertwined, as Figure 1 shows. This diagram expresses the dialogic space represented by the process of curriculum making (as distinct from curriculum design, curriculum planning or curriculum development each of which carries a different connotation). In curriculum making the conceptually distinct notions of curriculum and pedagogy are merged. However, even in curriculum making (and we argue that all classroom teachers are inescapably curriculum makers to a degree), there is a need to ask and have a means to answer the basic curriculum question: what shall I teach? 
In other words, we argue that a national curriculum laid down in law cannot, on its own, answer the curriculum question. This realisation gave rise to the riddle ${ }^{3}$ : "When is a curriculum not a curriculum? Answer: when it's a national curriculum". The severe limitation implied by this riddle on what can be accomplished by producing a national curriculum almost certainly translates into different national settings and jurisdictions around the world, even those which prefer to designate national 'standards' in detail, rather than a short and rather spare 'curriculum' framework as is now being proposed in England. It is good to remember the truth gleaned from extensive research in the field of educational assessment over decades, that standards are made and set by those who apply and use them: they do not exist as objective entities that can simply be picked up and 'delivered'.

\section{Background: where have we come from? (1988-2008)}

The 1988 Education Reform Act was a watershed moment in the English (and for a period, the Welsh) education system ${ }^{4}$. A national curriculum was to be created for the first time under the banner of 'raising standards', presented as part of a wider project to reverse national economic and social decline (Goodson, 1994 p.96). Politically, the Act represented a considerable shift of power away from professional educationalists to central government (Bennetts, 1993, p.6), and established a strong role for the state in deciding what should be taught. We have already indicated this was based on a faulty model of 'command and control', but it is easy to understand why the government of the day went for it: right up to the 1970s governments had shown no interest in the contents of schooling, but the deep economic crisis of that decade put an end to that laisséz faire thinking.

Looking back over nearly a quarter of a century, it might now seem that geography's place in the National Curriculum is assured and has become permanent. But its place was by no means certain and to this day lobbying activity by the GA which was so vital at the time (see Bailey 1991; Bailey and Binns 1987; Daugherty 1989; Rawling 2001; Walford 1989) has had to continue (for example with the GA's 2009 'Manifesto' called A Different View[GA 2009]). However, the resulting first Geography National Curriculum (GNC) (DES 1991) had a number of strengths. Geography became a statutory subject for study by all children from 5-16 years. It re-established place and locational knowledge, neglected by curriculum development in the 1970s and 1980s (Rawling 2001 p.40, 44), and created a balance between physical, human and environmental geography (Marsden 1995 p.169).

The GNC was less successful in integrating geographical enquiry, whilst geographical issues and material involving values and attitudes were actively marginalised. There were also significant structural weaknesses, particularly the lack of distinction between specifying content and the assessment requirements. A fundamental weakness now widely acknowledged was the attempt to spell out in detail the extensive coverage of the subject as a whole in every key stage. In hindsight we can see that the emphasis on breadth rather than depth tended to depress rather than raise expectations, and the content specificity appeared to impress on teachers the importance of content

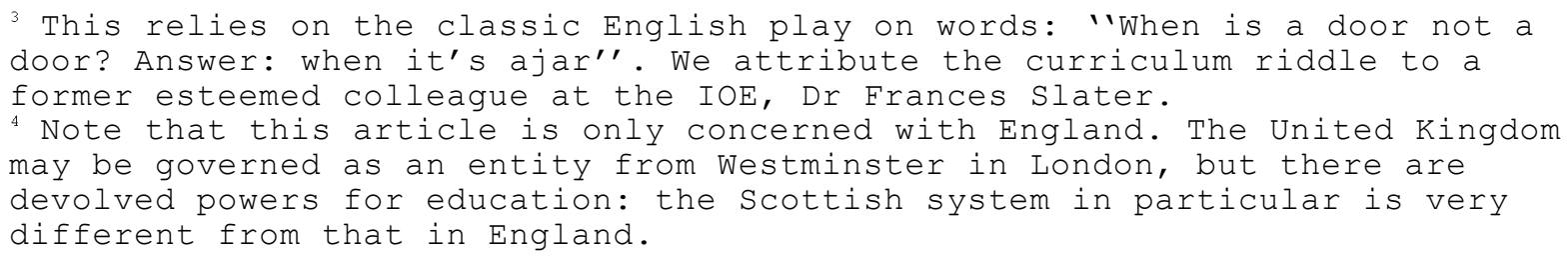


coverage and delivery. For a number of commentators, although geography had found its 'place in the sun' (Bailey 1991) the final curriculum document was overfull, difficult to implement and quickly became a straitjacket (see Robinson 1992, Butt 1997; Lambert 2004).

There was considerable pressure from the start for reductions in content and assessment requirements. Thus, geography quickly became an optional subject again for 14-16 years olds in the first of several revisions to the National Curriculum in 1995. Thus began a process whereby, at each successive review, the GNC evolved further from the original detailed and prescribed version towards a framework which sampled from the discipline, so securing a basic entitlement for pupils but putting more responsibility on teachers to develop a balanced curriculum (Lawton, 1996) - a demanding if not impossible task, especially for non-specialist teachers in primary schools, (as successive official reports testify: e.g. Ofsted 2008, Ofsted 2011). Table 1 provides both a summary and analysis of this evolution of the national curriculum. Alongside considerable continuity in the framework of knowledge and understanding of places, geographical themes and enquiry and skills (see Rawling, 2001 p. 81, and Hopkin, 2013 pp. 32-35), by 1999 this process resulted in:

- an increased articulation of aims;

- significant reductions in the specified content and increased use of illustrative examples, with less breadth but increased opportunities for depth, and more distinctive key stages;

- changes in content focus, especially the inclusion of themes such as sustainable development and globalisation relevant to a rapidly-changing world and related to geography's humanistic and welfare tradition;

- in assessment terms, a move from atomised 'statements of attainment' to Level Descriptions, enabling a clearer (but not unproblematic) definition of standards, expectations and progression.

Table 1 Here

\section{Foreground: the current debates (2008-2013)}

Table 1 shows that by 2009 geography teachers in the middle or latter part of their career would have experienced the evolution of the National Curriculum through three versions at Key Stages 1 and 2 (DES 1991; DfE 1995; DfEE/QCA 1999) and four versions for Key Stage 3 (DCSF/QCA 2007).

It might be thought that in 2009, with a recently published GNC for Key Stage 3 and a new primary version in preparation, the position of geography was secure. However, although the National Curriculum was statutory, in many primary schools geography appeared to be marginalised: it had even been suspended from the curriculum for one year (along with history) in 1998, the result of the relentless pressure from government on schools to improve children's scores in literacy and numeracy. In some secondary schools the place of geography in the curriculum was undermined by 
the re-emergence of 'themed' integrated courses and curriculum experimentation driven by the rising interest in competence or skills-based curricula deemed to be fit for the $21^{\text {st }}$ century.

The erosion of subjects by advocates of skills-based learning programmes was greatly encouraged by the loosely structured 2008 version of the secondary National Curriculum. Despite the steadily increasing responsibility for the curriculum noted earlier, teachers' work in the early years of the twenty-first century seemed to be defined more by pedagogy and technical delivery rather than their own subject knowledge and their capacity for disciplined geographical innovation (Roberts 2010, Lambert 2011). In part this resulted from the demands of high stakes testing and school accountability, but the concerns raised about the erosion of subject knowledge inadvertently anticipated the 2014 national curriculum reform.

As Table 1 shows, the 2014 review is a clear and unambiguous attempt by government to enhance 'traditional' subjects and the knowledge-led contents of curriculum and of teaching. It has some features in common with the 1991 GNC therefore, but there is a difference in vision between the subject community and the government in terms of the purpose and indeed nature of knowledge in the school curriculum. This alternative vision is expressed most fully in the Geographical Association's (GA) Manifesto for geography A Different View (GA 2009; Lambert 2009b) (See Table 2). Whilst the Manifesto certainly argues for the value of geographical knowledge (and the discipline as a resource), it emphatically does not argue for a return to the 1991 curriculum. Geographical knowledge in the National Curriculum of 1991 was provided as a 'given' - the origin of which was uncontested: it simply 'existed'. The implication was that it was fixed and immutable (although ironically the USSR, which was named on the curriculum, disintegrated soon after its publication!) and the role of the teacher was to 'impart' this. Such a content-rich curriculum encourages poor teaching in which teachers have little time to engage children into the 'space of reasons' (Bakhurst 2011). They instead focus only on 'covering' the content: geography becomes just 'one thing after another' (to misquote The History Boys) with little sense of overarching purpose or narrative. Such a conception of curriculum and knowledge aligns with what Young and Muller have called a Future 1 curriculum (See Table 3).

\section{Table 2 The role of the subject organisations.}

In England there is one subject association, the Geographical Association (GA) and one learned society, the Royal Geographical Society with Institute of British Geographers (RGS/IBG); both also have considerable reach to other UK nations and beyond. As well as providing services to their members, such as journals, professional development and teaching resources, both devote considerable energy to making the case for geography in the curriculum, and lobbying government.

A significant example is the GA's Manifesto for geography A Different View (GA 2009; Lambert 2009b). Weighty in argument and beautifully designed, it includes chapters on geography as a curriculum resource, thinking geographically (see Jackson 2006), investigating and exploring geography, and fieldwork. There are also chapters on several distinctive ideas and approaches developed by the $G A$, including: 
- living geography: bringing 'contemporary context and real world enquiry into the classroom' to help make sense of the big challenges facing the world (GA 2009 p.13)

- young people's geography: the idea that young people's interests, experiences, aspirations and curiosity should help shape the curriculum

- curriculum making: the belief that teachers should be 'autonomous professionals driven by educational goals and purposes' balancing teacher knowledge, students' interests and needs, and a dynamic subject discipline (ibid. p.27).

www.geography.org.uk/adifferentview

\section{Table 3 Three Alternative Curriculum Futures}

F1 subject delivery - of knowledge for its own sake; traditional subjects: under-socialised knowledge

F2 skills and 'learning to learn' - knowledge is constructed: over-socialised knowledge; subject divisions are artificial. Themes. Experiential.

F3 subjects are not given (as in F1), but not arbitrary either (as in F2) knowledge development led by '... the epistemic rules of specialist communities' to provide ways to understand the world and take pupils' beyond their everyday experience.

(after Young and Muller 2010)

There are several ways in which an F1 curriculum was and is inadequate. It makes no allowance at all for the advances made through educational studies in our understanding of how children learn. It also makes no attempt to meet the agency of young people as 'human knowers', including the significance of assessing their prior knowledge. A Future 1 curriculum also fails to accept the nature and significance of a wider disciplinary community (in this case of geographers) and the ways in which that community has created the discipline of geography - through its arguments and contests and 'paradigm shifts'. It is partly because of (some) these inadequacies of an F1 curriculum that the English education system came to be in thrall of an alternative future, what Young and Muller call the Future 2 curriculum. Here, it is the social construction of knowledge that becomes the unchallenged orthodoxy. In F2, subject disciplines are also seen as human constructions (correctly) and as such are therefore arbitrary and can be dispensed with. Such incorrect conclusions are often linked to the idea that the acquisition of knowledge can be delegated to the use of an internet search engine. What matters, in other words, is that children learn the skills of information retrieval, analysis and 
communication - in short, learn how to learn with an emphasis on the soft skills of collaboration. This approach puts the learner at the centre; we differentiate learning, we facilitate learning, we personalise learning: but we do not talk much about what to teach. It is not the place in this paper, but it would be interesting to explore the true cost of underestimating the power and the importance of the disciplines in terms of progressive and critical thought; for instance, to paraphrase David Wadley's (2008) interesting remark, to what extent does an F2 curriculum contribute to a 'dulling of our ability to think for or beyond ourselves?' (p. 650).

The GA's Manifesto, chiefly through its insistence on identifying the discipline as a resource and the idea of curriculum making, was designed to help resist the F2 future. In doing so, it carefully and selfconsciously distanced geography from going back to an F1 future, through its deployment of 'living geography' and its identification of the significance of 'young people's geographies' as noted above. However the keystone to the Manifesto's position was, and remains, the responsibility placed on teachers as curriculum makers focussed by the idea of nurturing and developing in children the capacity to 'think geographically'. Deep deliberative thought about the world requires disciplinary knowledge, and through this the development of discernment, argument and systematic understanding. This in turn requires at least a foothold on how geographical knowledge is made and contested, what Richard Peters called education as 'initiation' (see Lambert 2009a). Thus, critical understanding, the educational prize valued most highly by teachers and educationists, is best taught through initiation into disciplined thought. Thus, the subjects, including geography, are not therefore entirely arbitrary as extreme F2-ists might argue, for there are discernible and important differences in thinking mathematically, scientifically, historically or geographically. It was Basil Bernstein (2000) who indicated that such access to what Michael Young has subsequently termed 'powerful knowledge' is the basis for societies to be able to think the unthinkable and the yet to be thought - quite different from the 'trainability' (also Bernstein's term) valued in generic and vocationally oriented programmes.

Although it was not known at the time (2009), the Manifesto was in effect arguing for a Future 3 curriculum. Underpinning F3 is the acceptance that schools - and the curriculum - are about knowledge first and foremost, but not in the static, given, sense of F1. Michael Young's influential notion of 'powerful knowledge' is key, as it enables a richer and more progressive concept of a knowledge-led curriculum than the more restricted proposals emanating from, for example E. D. Hirsch $(1987,2007)$ which have evidently been highly influential on the government's 2014 National Curriculum proposals. As Table 4 shows, 'powerful knowledge' (or more simply perhaps, disciplinary knowledge) is crucial in differentiating schools from the everyday: schools are in the knowledge development business and it is this that makes them special. This article is not the place to open up a discussion on this (but see alternative viewpoints in White 2007 and Young 2009), save to say that one of Young's major points is that it is often less advantaged children who experience curricula which (perhaps inadvertently) deny them access to powerful knowledge by adopting forms of innovations that stress generic competences and vocational 'relevance' rather than knowledge development.

Table 4 Powerful Knowledge (PK)

PK refers to the knowledge children and young people are unlikely to acquire at home or in the workplace

PK is knowledge young people will need if they are to become active citizens and workers in the complex modern world, sometimes called the 'knowledge society'

PK is characterised by these features. It is often, but not always, 


\section{The National Curriculum in 2014 and the possibility of Future 3.}

2010 saw the election of a new Conservative-Liberal Democrat coalition government in the UK and the publication of its Schools White Paper The Importance of Teaching (DfE 2010) which launched a wholesale review of the National Curriculum in England. As we have noted above, E.D. Hirsch's ideas, that pupils need knowledge to gain the 'cultural literacy' required to function in society (Hirsch, 1987, 2007; see also Dowgill and Lambert, 1992, and Firth 2012, 2013) were influential. Thus the new curriculum would focus on 'the core subject knowledge that every child and young person should gain at each stage of their education' (DfE 2010 p.11). However, the school system in England is now to all intents and purposes a high stakes, free market driven by the neo-liberal credo of 'choice': any vestige of the national curriculum as a means of government 'command and control' is now truly broken. Despite the new national curriculum being a 'tighter, more rigorous, model of the knowledge which every child should expect to master' (ibid p.10), and advocating 'a greater focus on subject content' (ibid p.42), the White Paper openly acknowledges this contradiction, allowing 'schools and teachers ... greater control over what is taught' ( $p .40)$. There is a basic tension between freeing teachers up from 'prescription, bureaucracy and central control' ( $p .40)$ and the desire to define and recast the curriculum in the government's own (largely traditionalist) terms.

In the context of our analysis in the previous sections however, the new stripped down National Curriculum, with its brief yet precise outline of the 'core of essential knowledge' in geography, offers an enormous opportunity for teachers to wrestle with their curriculum making responsibilities (see Figure 1). The revised programme of study certainly signals the knowledge domain of geography to be 
addressed between the ages of 5 and 14 in schools, but in around four pages in total does not express the detail of what should be taught. In avoiding lists of content it invites teachers to create a curriculum of engagement rather than delivery. It is an opportunity for specialist geography teachers to break away from the dead hand of 'deliverology' (Pring 2013) and to engage, as 'knowledge workers' (see Lambert and Morgan 2010 chapter 4), with the subject and to initiate to some degree their students into thinking geographically. The goal was expressed effectively in the GA's 2009 Manifesto which took its title from Richard Peters' memorable phrase, that to be educated is not only to arrive at a destination (signified for example by an examination certificate) but to be able to 'travel with a different view' (armed with new or richer conceptual understanding, to see things differently). This we believe to be a signifier of an $\mathrm{F} 3$ curriculum and it is this possibility that is available: the making of a knowledge-led curriculum which does not take us back the future (and F1).

To achieve an $\mathrm{F} 3$ curriculum is beyond any national curriculum programme of study: words on a page cannot do this. Teachers are the curriculum makers and they can do this: but we acknowledge that this requires high levels of geographical knowledge and pedagogic skill from teachers and not a small amount of confidence and support. Margaret Roberts (2013) has produced a rigorous professional framework which may be seen as a platform for the localised curriculum making that the latest national curriculum (and in different ways its predecessors) make possible. Entitled Geography Through Enquiry, the book is unequivocal about the need for geography lessons to contain geographical content. But equally Roberts is unequivocal about the need for geography lessons to make a space for reasoning and meaning making. In this sense geography lessons induct young people through constructivist activity to the arena of geographical knowledge making. The F3 knowledge-led curriculum reminds us that this induction must also be to the wider discipline.

\section{Conclusion}

This paper began with a discussion of Bill Marsden's analysis of the dynamic between the educational, subject and social domains influencing the geography curriculum. In response, we have taken the analysis further to propose a progressive vision of a knowledge based geography curriculum, developing Young and Muller's notion of a Future 3 curriculum. Whereas geography's place in the national curriculum for England has been achieved, albeit against a background where this place is constantly contested, what has not yet been achieved, at least universally across primary and secondary schools in England, is the Future 3 geography which the GA Manifesto began to advocate in 2009, albeit implicitly. This is a curriculum made by teachers and which takes its cue as much from the subject discipline as from the official programme of study. As Roger Firth (2013) acknowledges, this may mean that teachers will 'need to better understand bodies of knowledge, the subject disciplines - and how they can be used in educational settings' (p71). Anecdotally, it is said that ministers claim that the 2014 national curriculum revision will be the last ever, that the 'core of essential knowledge' is relatively stable and enduring. This is an intriguing thought, and may be borne out if teachers, supported by the subject community, are able to accept responsibility for a 'disciplinary model' (Firth 2012) in their curriculum making. 
So how will future historians regard the 2014 version of the geography in the national curriculum? Firstly, until 2010 it would have been reasonable to assume that its development was evolutionary, as Table 1 indicates. The current experience may suggest a more cyclical process - the government reversing past trends and attempting to 'restore' old traditions. Indeed, as we noted above, the government is said to regard the current review as a permanent solution to curriculum change: a stable and enduring articulation of 'core knowledge'. A lesson from the history is that attempts to specify the curriculum in detail from the centre have limited traction and endurance - and the 2014 programme of study sensibly avoids detailed lists. But in any case, for good or ill, in practice there is considerable underlying continuity in geography, as experienced by pupils, from one version of the National Curriculum to another (Roberts, 1995, 1998). In a way this testifies to the significance of localised curriculum making.

Future historians may also be in a better position to see how the background tensions and even contradictions in the policy environment play out. With the national state school system in England part way to disintegration, and the effective removal of the 'national' from the geography national curriculum, it is clear that the notion that all pupils at particular ages are entitled to a particular set of geographical experiences is also breaking down. It may be that these trends offer a space for commercial and/or 'third sector' organisations, such as publishers, subject associations or other educational entrepreneurs, to play a more prominent role in developing a different sense of entitlement and standards.

This paper has argued that the revised GNC provides a basis for a curriculum for engagement rather than a curriculum of 'delivery'. In geography this requires skilful and above all knowledgeable teachers: equipped with not only professional knowledge (of learning, pedagogy and curriculum) but of disciplinary knowledge too. Thus the school teacher's job, as well as making the space and opportunity for children to engage with data and in 'meaning making' by learning through enquiry is to induct or initiate young people into the (disciplinary) world of what is known under the domain of geography and how 'we' know it.

In the end the national standards - in the case of England, expressed through the national curriculum programme of study - are, as we noted earlier in this paper, achieved by those who use and apply them. This emphatically is not the government, but teachers, locally, in their classrooms. This involves the professional engagement of teachers with a progressive view of geographical knowledge and its value within the context of educational aims. This is 'curriculum making' on a grand scale - an approach that may well prove more sustainable than even the current national standards. 


\section{References}

Bakhurst, D. (2011) The Formation of Reason London: Wiley-Blackwell

Bailey, P. (1989) 'A place in the sun: the role of the Geographical Association in establishing geography in the National Curriculum of England and Wales, 1975-89', Journal of Geography in Higher Education, 13, 2, pp. 149-57.

Bailey, P. (1991) 'Securing the Case of Geography in the National Curriculum of English and Welsh Schools: a study of the politics and practicalities of curriculum reform, Occasional Paper, Leicester University.

Bailey, P. and Binns, A. (eds.) (1987) A Case For Geography, Sheffield: Geographical Association.

Bennetts, T. (1993) 'Reflections on the development of geography in the National Curriculum', in R. Walford, and P. Machon, (eds.) Challenging Times: Implementing the National Curriculum in Geography, Papers from the Charney Manor Conference 1993, Cambridge: Cambridge Publishing Services.

Bennetts, T. (2005) 'The Links between Understanding, Progression and Assessment in the Secondary Geography Curriculum' Geography, 90, 2, pp. 152-170.

Bernstein, B. (2000) Pedagogy, Symbolic Control and Identity: Theory, research, critique, Lanham: Rowman and Littlefield

Biddulph, M. (2011) Young People's Geographies: implications for secondary school geography, in Butt, G. (ed) Geography, Education and the Future, London: Continuum

Biddulph, M. (2013) Where is the curriculum created? in Lambert, D. and Jones, M. (eds) Debates in Geography Education, London: Routledge

Butt, G. (1997) An Investigation into the Dynamics of the National Curriculum Geography Working Group (1989-1990), unpublished PhD thesis, Faculty of Education and Continuing Studies, University of Birmingham.

Daugherty, R. (1989) Geography in the National Curriculum, Sheffield: Geographical Association.

DCSF/QCA (2007) The National Curriculum: statutory requirements for Key Stages 3 and 4, London: DCSF/QCA.

DES (1991) Geography in the National Curriculum (England), London: HMSO.

DfE (1995) Geography in the National Curriculum: England, London: HMSO

DfE (2010) The Importance of Teaching: Schools White Paper, (online) https://www.education.gov.uk/publications/standard/publicationdetail/page1/CM\%207980 (accessed 27 March 2013). 
DfE (2011a) The Framework for the National Curriculum - A report by the Expert Panel for the National Curriculum review, (online)

https://www.education.gov.uk/publications/eOrderingDownload/NCR-

Expert\%20Panel\%20Report.pdf accessed 15 April 2013.

DfE (2011b) 'Press Notice: National Curriculum review launched' (online)

https://www.education.gov.uk/inthenews/inthenews/a0073149/national-curriculum-review-

launched (accessed 2 April 2013).

DfE (2013) The National Curriculum in England, Framework document for consultation, Department for Education, (online)

http://media.education.gov.uk/assets/files/pdf/n/national\%20curriculum\%20consultation\%20\%20framework\%20document.pdf (accessed 22nd March 2013).

DfEE/QCA (1999) The National Curriculum: handbook for primary teachers in England, Key Stages 1 and 2, HMSO, London.

Dowgill, P. and Lambert, D. (1992) 'Cultural Literacy and School Geography', Geography, 77, 2, pp. 143-151.

Firth, R. (2012) 'Disordering the coalition government's 'new' approach to curriculum design and knowledge: the matter of the discipline' Geography, 97, 2, pp. 86-94.

Firth, R. (2013) 'What constitutes knowledge in geography?' in Lambert, D. and Jones, M. (eds.) Debates in Geography Education, London and New York: Routledge

GA (2009) A Different View: a manifesto from the Geographical Association, Sheffield: Geographical Association, (online) http://www.geography.org.uk/resources/adifferentview/\#top (accessed 22nd March 2013).

GA (2010) Curriculum Making, (online)

http://www.geography.org.uk/cpdevents/curriculummaking

GA (2011a) The Geography National Curriculum: GA Curriculum Proposals and Rationale, (online) http://www.geography.org.uk/download/GA GIGCCCurriculumProposals.pdf (accessed 15 April 2013).

GA (2012) Thinking Geographically, (online)

http://www.geography.org.uk/download/GA GINCConsultation12ThinkingGeographically.pdf (accessed 15 April 2013).

Goodson, I.F. (1987) School Subjects and Curriculum Change, Lewes: Falmer.

Goodson, I.F. (1988) 'Becoming a school subject' in Goodson, I.F. (ed.) The Making of Curriculum: Collected Essays; first edition, Brighton: Falmer

Goodson, I.F. (1994) Studying Curriculum: cases and methods, Buckingham: Open University Press. 
Hirsch, E.D. (1987) Cultural Literacy: What Every American Needs To Know, Boston, Houghton Mifflin.

Hirsch, E.D. (2007) The Knowledge Deficit, Boston: Houghton Mifflen.

Hopkin, J. (2011) 'Progress in geography', Geography, 96, 3, pp. 116-123.

Hopkin, J. (2013) 'What is Key Stage 3 for?' in Lambert, D. and Jones, M. (eds.) Debates in Geography Education, London and New York: Routledge

Jackson, P. (2006) 'Thinking Geographically' Geography, 91, 3, pp. 199-204.

Lambert, D. (2004) Geography, in White J (ed) Rethinking the School Curriculum, London:

RoutledgeFalmer

Lambert, D. (2009a) Geography in education: Lost in the post? Inaugural professorial lecture, University of London, Institute of Education

Lambert D (2009b) A Different View, Geography, 94, 2, pp 119-125

Lambert, D. (2011) Reviewing the case for geography, and the 'knowledge turn' in the English national curriculum, The Curriculum Journal, 22, 2, 147-157.

Lambert, D. (2013) 'Collecting our thoughts: school geography in retrospect and prospect' Geography, 98, 1, pp.10-17.

Lambert D (2013b) Geography in school and a curriculum of survival, Theory and Research in Education, 11, 1, pp 85-98

Lambert, D. and Morgan, J. (2010) Teaching Geography 11-18: a conceptual approach, Maidenhead: Open University Press

Lawton, D. (1989) Education, Culture and the National Curriculum, London, Hodder and Stoughton.

Lawton, D. (1996) Beyond the National Curriculum: teacher professionalism and empowerment, London: Hodder \& Stoughton.

Marsden, W.E. (1995) Geography 11-16: Rekindling good practice, London: David Fulton.

Marsden, W.E. (1997) 'On Taking the Geography out of Geographical Education', Geography, 82, 3: pp. 241-52.

Ofsted (2008) Geography in schools: changing practice, London, Ofsted ref 070044, (online) http://www.ofsted.gov.uk/resources/geography-schools-changing-practice, accessed 8 April 2013.

Ofsted (2011), Geography: Learning to make a world of difference, London: Ofsted http://www.ofsted.gov.uk/resources/geography-schools-changing-practice accessed 8 April 2013.

Pring, R. (2013) The Life and Death of Secondary Education For All, Abingdon: Routledge 
Rawling, E. (2001) Changing the Subject: the impact of national policy on school geography 1980 2000, Sheffield: Geographical Association.

Reiss, M. And White, J. (2013) An Aims Based Curriculum: the significance of human flourishing for schools, London: IOE Press

Roberts, M. (1995) 'Interpretations of the Geography National Curriculum: a common curriculum for all? Journal of Curriculum Studies, 27, 2, pp. 187-205.

Roberts, M. (1998) 'The Impact and the Legacy of the 1991 Geography National Curriculum at Key Stage 3', Geography, 83, 1, pp. 15-27.

Roberts, M. (2010) 'Where's the geography? Reflections on being an external examiner' Teaching Geography, 35, 3, pp. 112-113.

Roberts, M. (forthcoming) Learning Geography Through Enquiry, Sheffield: Geographical Association Robinson, R. (1992) 'Facing the Future: Not the National Curriculum', Teaching Geography, 17, 1, pp. 31-32.

Scoffham, S. (2011) 'Core knowledge in the revised curriculum' Geography, 96, 3. pp. 124-130.

Standish, A. (2009) Global Perspectives in the Geography Curriculum: reviewing the moral case for geography, London, Routledge.

Standish, A. (2012) The False Promise of Global Learning: why education needs boundaries, London: Continuum

Stoddard, D.R. (1981) 'Ideas and Interpretations in the History of Geography', in D.R. Stoddart, (ed.) Geography, Ideology and Social Concern, Oxford, Basil Blackwell.

Wadley D (2008) The garden of peace. Annals of the Association of American Geographers 98(3): 650-685.

Walford, R. (1989) 'Geography and the National Curriculum: a chronicle and a commentary', Area, 21, 2, pp. 161-6.

White J (2007) What are schools for, and why? Impact No 14 Salisbury: The Philosophy of Education Society of Great Britain.

Winter C (2009) Geography and education I: the state of health of geography in schools, Progress in Human Geography, 33, 5 pp 667-676

Winter, C. (2011) Geography and education II: policy reform, humanities and the future of school geography in England, Progress in Human Geography, 36, 2, pp 254-262

Winter, C. (2012) Geography and education III Update on the development od school geography in England under the Coalition government, Progress in Human Geography 36, 5, 
Young, M. (2008) Bringing Knowledge Back In, London: Routledge.

Young, M. (2009). What are schools for? In Daniels, H., Lauder, H. and Porter, J. (eds), Knowledge, Values and Educational Policy London: Routledge.

Young, M. And Muller, J. (2010) Three Educational Scenarios for the Future: lessons from the sociology of knowledge, European Journal of Education, 45, 1: 11-27 


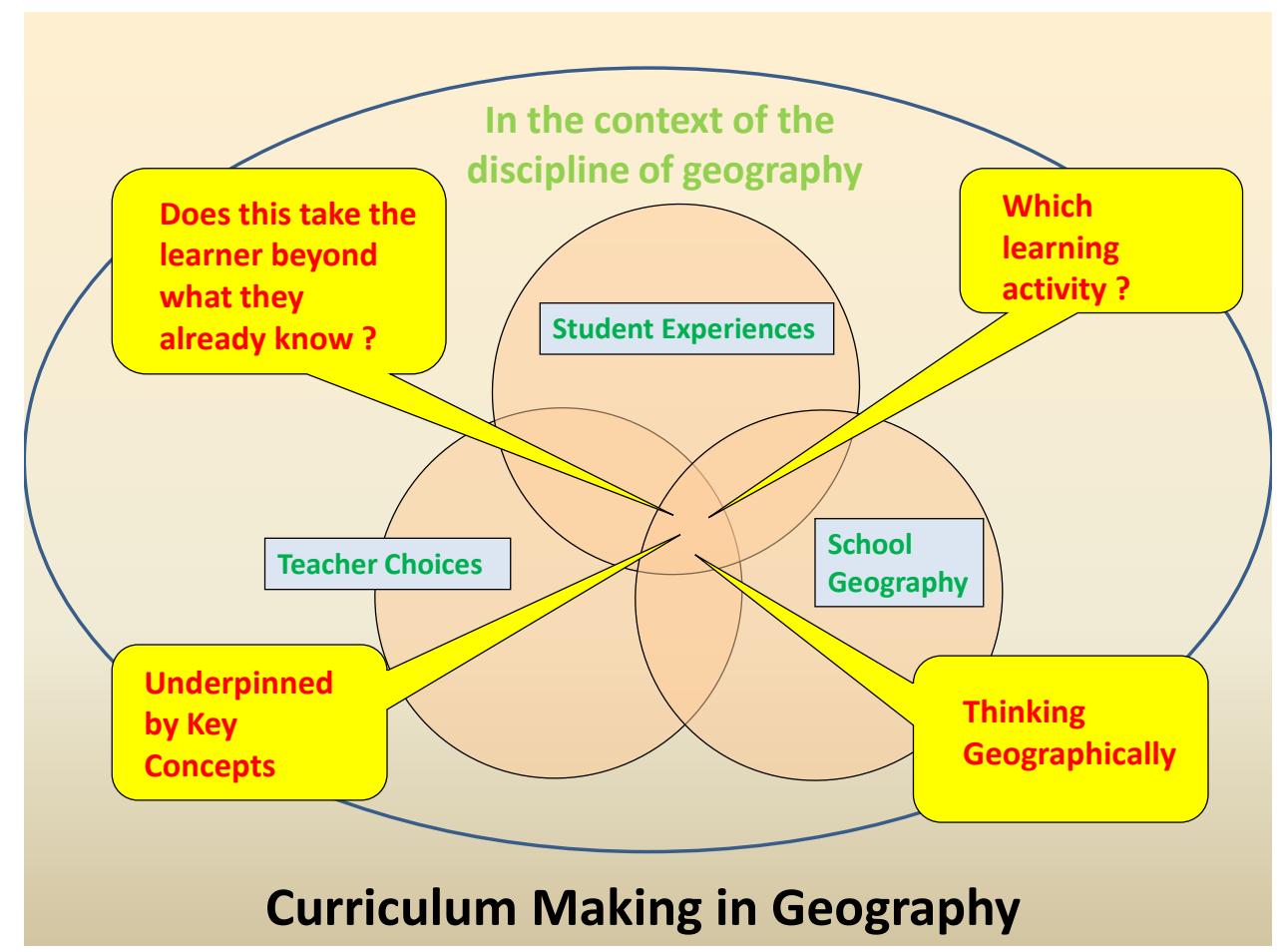

Figure 1 Curriculum Making for geography teachers

The diagram shows the balance that needs to be struck between competing priorities - the needs of students as learners, the geography curriculum and pedagogy. This thinking takes place within the context of the discipline and the teacher's grasp of the value of geographic thought to the education of all young people. It is noted that the teachers geographical identity influences in some cases profoundly, not only how the school curriculum is thought about and developed, but on how we understand students' experiences and indeed appropriate pedagogies in the subject. 